\title{
Women Are More Susceptible to Caries but Individuals Born with Clefts Are Not
}

\author{
Aditi Jindal,, 2 Michelle McMeans, ${ }^{1,2}$ Somnya Narayanan, ${ }^{1,2}$ Erin K. Rose,, 2 \\ Shilpa Jain, ${ }^{3}$ Mary L. Marazita, ${ }^{1,2}$ Renato Menezes, ${ }^{1,2}$ Ariadne Letra, ${ }^{1,2}$ Flavia M. Carvalho, ${ }^{4}$ \\ Carla A. Brandon, ${ }^{1,2}$ Judith M. Resick, ${ }^{1,2}$ Juan C. Mereb, ${ }^{5}$ Fernando A. Poletta, ${ }^{6,7,8}$ \\ Jorge S. Lopez-Camelo, ${ }^{6,7,8,9}$ Eduardo E. Castilla, ${ }^{7,8,10}$ Iêda M. Orioli, ${ }^{4,8}$ \\ and Alexandre R. Vieira ${ }^{1,2,11}$ \\ ${ }^{1}$ Departments of Oral Biology, School of Dental Medicine, University of Pittsburgh, Pittsburgh, PA 15261, USA \\ ${ }^{2}$ Center for Dental and Craniofacial Genetics, School of Dental Medicine, University of Pittsburgh, Pittsburgh, PA 15261, USA \\ ${ }^{3}$ Division of Pediatric Hematology-Oncology, Children's Hospital of Pittsburgh, Pittsburgh, PA 15224, USA \\ ${ }^{4}$ Department of Genetics, Center of Health Sciences, Institute of Biology, Federal University of Rio de Janeiro, Rio de Janeiro, \\ RJ, Brazil \\ ${ }^{5}$ (ECLAMC) Latin American Collaborative Study of Congenital Malformations at Hospital de Area El Bolsón, Río Negro, Argentina \\ ${ }^{6}$ (ECLAMC at CEMIC) Center for Medical Education and Clinical Research, Buenos Aires, Argentina \\ 7 (CONICET) National Research Council of Argentina, Argentina \\ 8 (INAGEMP-CNPq)National Institute of Population Medical Genetics, Brazil \\ 9 (ECLAMC at INAGEMP-CNPq) National Institute of Population Medical Genetics in CEMIC, Buenos Aires, Argentina \\ ${ }^{10}$ (ECLAMC at IMBICE ) Multidisciplinary Institute of Cellular Biology, La Plata, Argentina \\ ${ }^{11}$ Pediatric Dentistry, School of Dental Medicine, University of Pittsburgh, Pittsburgh, PA 15261, USA
}

Correspondence should be addressed to Alexandre R. Vieira, arv11@pitt.edu

Received 2 March 2011; Accepted 20 April 2011

Academic Editor: Figen Seymen

Copyright () 2011 Aditi Jindal et al. This is an open access article distributed under the Creative Commons Attribution License, which permits unrestricted use, distribution, and reproduction in any medium, provided the original work is properly cited.

The identification of individuals at a higher risk of developing caries is of great interest. Isolated forms of cleft lip and palate are among the most common craniofacial congenital anomalies in humans. Historically, several reports suggest that individuals born with clefts have a higher risk for caries. Caries continues to be the most common infectious noncontagious disease worldwide and a great burden to any health system. The identification of individuals of higher susceptibility to caries is of great interest. In this paper, we assessed caries experience of 1,593 individuals from three distinct populations. The study included individuals born with clefts, their unaffected relatives, and unrelated unaffected controls that were recruited from areas with similar cultural pressures and limited access to dental care. DMFT/dmft scores were obtained, and caries experience rates were compared among the three groups in each geographic area. Individuals born with clefts did not present higher caries experience in comparison to their unaffected relatives or unrelated unaffected controls. Women tend to present higher caries rates in comparison to men. Our work provides strong evidence that individuals born with clefts are not at higher risk to caries; however, women tend to have more severe caries experience.

\section{Introduction}

The identification of individuals at a higher risk of developing caries is of great interest. Among the suggested high risk individuals are the ones born with cleft lip and palate. Most reports suggest individuals born with clefts have a higher risk of caries [1-19]. There are studies however that did not find any difference in caries experience between individuals born with clefts and unaffected controls [2026]. It has been proposed that the higher incidence of caries in the cleft populations reported in many studies are likely due to poor study design [27], diet rich in sugars $[28,29]$, poor oral hygiene [30-32], lack of motivation to perform regular preventive dental home care for the children 
$[28,29]$, low fluoride exposure [20, 24], early infection by Streptococcus mutans and lactobacilli [33, 34], teeth misalignment [35], and high prevalence of dental erosion [24]. The most recent meta-analysis of data on the frequency of caries in individuals born with clefts was unable to conclude that individuals born with these defects have higher frequency of caries [27]. Since there is still no consensus in the literature regarding this matter, we decided to analyze caries experience data in three independent populations of lower socioeconomic status and with limited access to dental care to test the hypothesis that individuals born with clefts have a higher caries susceptibility. Our analysis suggests individuals born with clefts are not more susceptible to caries.

\section{Subjects and Methods}

All subjects were recruited as part of studies aiming to identify genetic factors contributing to clefts. Individuals born with isolated forms of cleft lip with or without cleft palate, their relatives, and unrelated unaffected individuals were invited to participate. The University of Pittsburgh Institutional Review Board, as well as the corresponding appropriate boards in each study site approved this project. All subjects provided written informed consent before participating in this study. Age appropriate documents were used for children between ages 8 and 13 years. Parents provided consent to children seven years of age and under.

In this study, caries experience data of 1,593 subjects were analyzed. Six hundred twenty-eight subjects were recruited from the Cebu province in the Philippines. Five hundred and ninety-four subjects were recruited from Guatemala (cities of Pueblo Nuevo Tiquisate, Retalhuleu, and Santa Cruz del Quiché). Finally, 371 subjects were recruited from the Patagonian region of Argentina (cities of ChoeleChoel, El Bolsón, Esquel, General Roca, IngenieroJacobacci, Maquinchao, El Maitén, Rio Colorado, San Antonio Oeste, San Carlos de Bariloche, Sierra Grande, and Valcheta). In all these sites, individuals were from modest socioeconomic backgrounds, with limited access to dental care, and similar regional cultural influences.

Caries experience was recorded by the DMFT index (Decayed, Missing due to caries, Filled Teeth) as recommended by the World Health Organization [36]. One of the authors (A. R. V.) was responsible for calibration of all the examiners. In addition to A. R. V., two individuals carried out the clinical examination, after being calibrated, in the Philippines, two individuals in Guatemala, and one individual in Argentina. ANOVA, chi-square, and Fisher's exact tests were used to determine if differences were statistically significant.

\section{Results}

Caries experience based on age and gender using two-way ANOVA was not statistically significantly different between individuals born with clefts and their relatives or unrelated unaffected individuals in all three study sites (Table 1).
Females tended to show higher levels of caries experience than males.

\section{Discussion}

Our results do not support the suggestion that individuals born with isolated cleft lip with or without cleft palate have higher caries experience. Our study includes individuals from a wide range of ages and three geographically independent sites. In these sites, both individuals born with clefts and individuals born without clefts were derived from the community, and our study does not include a sample of convenient controls recruited from a hospital or composed by dental students.

The use of DMFT scores has its own limitations. This scoring system was created to be applied at 12 years of age. As one gets old, the DMFT score may increase not only due to new caries lesions, but also due to prosthetic work to replace missing units (which would increase the "F" component of the DMFT score, and tooth losses due to periodontal diseases or trauma, which would increase the "M" component of the DMFT score). Our study design minimizes this issue since the study subjects typically had no dental fillings and our protocol included questions related to history of dental trauma and reasons why teeth may have been extracted to avoid counting missing teeth extracted for reasons other than caries. Also, subjects included in this study were not exposed to any preventive dental measures and went to the dentist to address concerns related to dental pain, which was usually resolved through extractions.

A number of variables have been associated with oral clefts. These include seasonal variation, parental age, maternal age, birth order, emotional stress, other maternal risks, and socioeconomic status (reviewed by [37-39]). It is hard to exclude chance correlations, and a number of these findings have not been reproduced. The only demographic variable consistently associated with oral clefts is ethnicity. In comparison to Whites, Asians and American Indians have a higher frequency of oral clefts, whereas African and African descents have a lower frequency $[40,41]$. Ethnicity can be a surrogate of lower socioeconomic status in some parts of the world, such as in the Americas, where Native Indians as an example tend to be disenfranchised [42]. However, the variation in frequency of oral clefts related to ethnicity also speaks in favor of a strong genetic component to the defect, which is likely influenced by many genes that can be modulated by the environment [43]. Lower socioeconomic status impacts access to care, and it has been suggested that children whose clefts had been surgically repaired have lower caries experience than those whose clefts had not been surgically repaired [18]. Since our study included families with lower socioeconomic status, our results are likely to be less influenced by the effects of inadvertently mixing individuals from different social strata.

It continues to intrigue the finding that females have a higher caries experience than males. Lukacs and Largaespada 


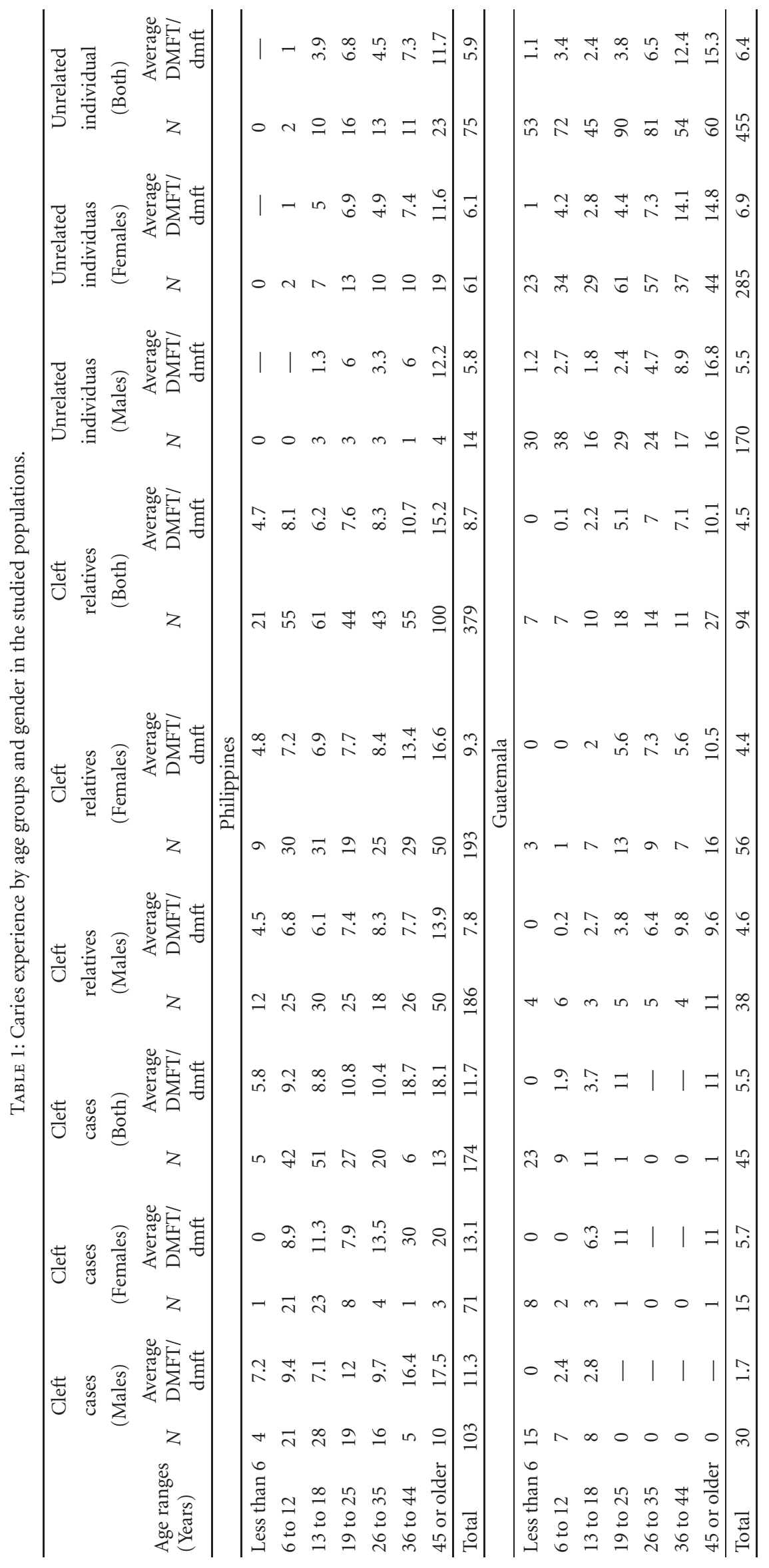




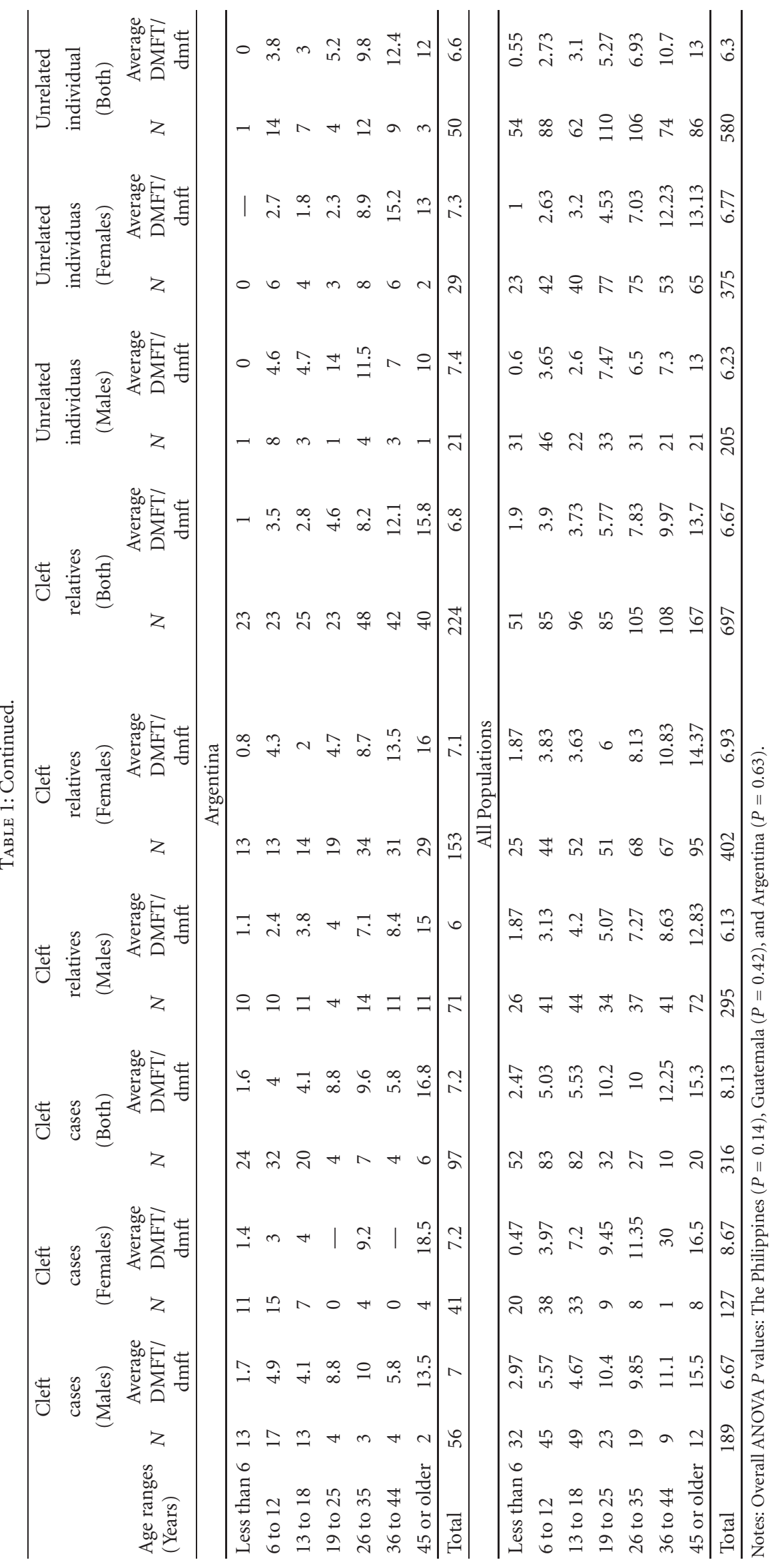


[44] and Lukacs [45] propose three working hypotheses to explain this phenomenon.

(i) Female sex hormones and associated physiological factors can significantly affect cavity formation. Evidence from animal models suggests that female estrogens, but not male androgens, correlate with caries rates. It is possible that there is a cumulative effect of estrogens, including fluctuations at puberty and high levels during pregnancy, that promotes caries.

(ii) Women produce less saliva than men do, reducing the removal of food residue from the teeth. During pregnancy, the chemical composition of saliva changes, reducing saliva's antimicrobial capacity.

(iii) Women have food cravings, variations in immune response, and aversions during pregnancy. Women have an aversion to meat in the first trimester and crave high-energy, sweet foods during the third trimester.

In theory, if hormonal or physiological factors work independently or in an additive manner in women, their potential impact on the women's oral health can be significant. Our data supports the fact that caries experience in women increases in a more significant rate with age than in men, in diverse ethnic groups from different ecological and cultural settings, which supports the assumption that women are under additional influences that increase their caries rates.

X-linked genetic variation could partly explain why men tend to have lower caries rates than women. Our previous genome-wide linkage scan provided evidence of the involvement of the locus Xq27.1 in caries susceptibility [46]. A nonparametric LOD $P$ value of .0005 was found when the analysis considered individuals with lower caries experience rates. Our candidate gene approaches considering genes involved in enamel formation also suggested an involvement of chromosome X (with an association with markers in amelogenin, located at Xp22.3-p22.1) in caries susceptibility $[47,48]$.

In summary, our work provides strong evidence that individuals born with clefts are not more susceptible to caries. Women appear to experience higher caries rates throughout life and research should focus on understanding why gender appears to play a role in caries susceptibility.

\section{Acknowledgments}

The authors thank subjects for their enthusiastic participation in this project. They are indebted to Children of Americas, Inc., for its support during the work in Guatemala. Melissa Carp revised the text for grammar and style. This work was supported by NIH Grants R21-DE16718 and R01-DE18914 (ARV), and R01-DE14899 and R01-DE16148 (MLM); by the AgenciaNacional de PromociónCientífica y Tecnológica (ANPCyT), Argentina, Grant number: PICTOCRUP 2005 no. 31101; by the Consejo Nacional de Investigaciones Científicas y Técnicas (CONICET), Argentina; and for
ECLAMC financial support from CNPq (National Research council of Brazil), process no. 573993/2008-4; INAGEMP.

\section{References}

[1] D. C. Johnsen and M. Dixon, "Dental caries of primary incisors in children with cleft lip and palate," Cleft Palate Journal, vol. 21, no. 2, pp. 104-109, 1984.

[2] G. Dahllöf, R. Ussisoo-Joandi, M. Ideberg, and T. Modeer, "Caries, gingivitis, and dental abnormalities in preschool children with cleft lip and/or palate," Cleft Palate Journal, vol. 26, no. 3, pp. 233-237, 1989.

[3] R. Ishida, Y. Yasufuku, A. Miyamoto, T. Ooshima, and S. Sobue, "Clinical survey of caries incidence in children with cleft lip and palate," Shoni Shikagaku Zasshi, vol. 27, no. 3, pp. 716-724, 1989.

[4] B. Bokhout, F. X. W. M. Hofman, J. van Limbeek, G. J. C. Kramer, and B. Prahl-Andersen, "Incidence of dental caries in the primary dentition in children with a cleft lip and/or palate," Caries Research, vol. 31, no. 1, pp. 8-12, 1997.

[5] T. A. Gregg, D. Johnson, and K. E. Pattinson, "Efficacy of specialist care for caries in the cleft child," International Journal of Paediatric Dentistry, vol. 9, Supplement, p. 61, 1999.

[6] C. J. Rivkin, S. E. Boulton, I. S. Hathorn, and P. J. Crawford, "Measurements of caries experience and dental attendance in cleft patients," International Journal of Paediatric Dentistry, vol. 9, supplement, p. 62, 1999.

[7] M. Budai, S. G. Kocsis, E. Kókai, I. Sági, and A. Mari, “Caries, gingivitis and dental abnormalities in patients with cleft lip and palateAz ajak- és szájpadhasadékos betegek cariológiai, parodontológiai és orthodontiai vizsgálata," Fogorvosi Szemle, vol. 94, no. 5, pp. 197-199, 2001.

[8] A. R. Hewson, C. M. McNamara, T. F. Foley, and J. R. Sandy, "Dental experience of cleft affected children in the west of Ireland," International Dental Journal, vol. 51, no. 2, pp. 73-76, 2001.

[9] M. Ahluwalia, S. R. Brailsford, E. Tarelli et al., "Dental caries, oral hygiene, and oral clearance in children with craniofacial disorders," Journal of Dental Research, vol. 83, no. 2, pp. 175-179, 2004.

[10] S. Besseling and L. Dubois, "The prevalence of caries in children with a cleft lip and/or palate in Southern Vietnam," Cleft Palate-Craniofacial Journal, vol. 41, no. 6, pp. 629-632, 2004.

[11] A. Kirchberg, A. Treide, and A. Hemprich, "Investigation of caries prevalence in children with cleft lip, alveolus, and palate," Journal of Cranio-Maxillofacial Surgery, vol. 32, no. 4, pp. 216-219, 2004.

[12] A. Al-Wahadni, E. Abu Alhaija, and M. Amin Al-Omari, "Oral disease status of a sample of Jordanian people ages 10 to 28 with cleft lip and palate," Cleft Palate-Craniofacial Journal, vol. 42, no. 3, pp. 304-308, 2005.

[13] M. Stec-Slonicz, J. Szczepańska, and U. Hirschfelder, "Comparison of caries prevalence in two populations of cleft patients," Cleft Palate-Craniofacial Journal, vol. 44, no. 5, pp. 532-537, 2007.

[14] T. Mutarai, W. Ritthagol, and J. Hunsrisakhun, "Factors influencing early childhood caries of cleft lip and/or palate children aged 18 to 36 months in southern Thailand," Cleft Palate-Craniofacial Journal, vol. 45, no. 5, pp. 468-472, 2008.

[15] M. Al-Dajani, "Comparison of dental caries prevalence in patients with cleft lip and/or palate and their sibling controls," Cleft Palate-Craniofacial Journal, vol. 46, no. 5, pp. 529-531, 2009. 
[16] V. Parapanisiou, S. Gizani, M. Makou, and L. Papagiannoulis, "Oral health status and behaviour of Greek patients with cleft lip and palate," European Archives of Paediatric Dentistry, vol. 10, no. 2, pp. 85-89, 2009.

[17] K. F. Britton and R. R. Welbury, "Dental caries prevalence in children with cleft lip/palate aged between 6 months and 6 years in the West of Scotland," European Archives of Paediatric Dentistry, vol. 11, no. 5, pp. 236-241, 2010.

[18] W. C. Zhu, J. Xiao, Y. Liu, J. Wu, and J. Li, "Caries experience in individuals with cleft lip and/or palate in China," Cleft Palate-Craniofacial Journal, vol. 47, no. 1, pp. 43-47, 2010.

[19] A. Hazza'a, M. Rawashdeh, K. Al-Nimri, and R. Al Habashneh, "Dental and oral hygiene status in Jordanian children with cleft lip and palate: a comparison between unilateral and bilateral clefts," International Journal of Dental Hygiene, vol. 9, no. 1, pp. 30-36, 2011.

[20] A. M. Lausterstein and M. Mendelsohn, "An analysis of the caries experience of 285 cleft palate children," The Cleft Palate Journal, vol. 29, pp. 314-319, 1964.

[21] A. Huth and W. Richter, "Incidence of caries and periodontal condition in patients with cleft lip and cleft palateKariesbefall und Parodontalzustand bei Patienten mit Lippen-KieferGaumen-Segel-Spalten," Stomatologie der DDR, vol. 29, no. 12, pp. 904-910, 1979.

[22] B. Zschieschack and R. Grabowski, "The influence of caries of the deciduous teeth upon development of the dentition in patients with cleft lip, jaw and palate," Journal of Orofacial Orthopedics, vol. 60, no. 3, pp. 215-224, 1999.

[23] V. S. Lucas, R. Gupta, O. Ololade, M. Gelbier, and G. J. Roberts, "Dental health indices and caries associated microflora in children with unilateral cleft lip and palate," Cleft PalateCraniofacial Journal, vol. 37, no. 5, pp. 447-452, 2000.

[24] J. R. Chapple and J. H. Nunn, "The oral health of children with clefts of the lip, palate, or both," Cleft Palate-Craniofacial Journal, vol. 38, no. 5, pp. 525-528, 2001.

[25] E. M. Bastos Lages, B. Marcos, and I. A. Pordeus, "Oral health of individuals with cleft lipc cleft palate, or both," Cleft Palate-Craniofacial Journal, vol. 41, no. 1, pp. 59-63, 2004.

[26] P. N. Tannure, E. C. Küchler, H. F. Romanos, A. R. Vieira, M. C. Costa, and J. M. Granjeiro, "Caries experience in individuals with cleft lip and palate," Pediatric Dentistry. In press.

[27] P. Hasslöf and S. Wetman, "Caries prevalence in children with cleft lip and palate-a systematic review of case-control studies," International Journal of Paediatric Dentistry, vol. 17, no. 5, pp. 313-319, 2007.

[28] Y. T. J. Lin and C. L. Tsai, "Caries prevalence and bottlefeeding practices in 2-year-old children with cleft lip, cleft palate, or both in Taiwan," Cleft Palate-Craniofacial Journal, vol. 36, no. 6, pp. 522-526, 1999.

[29] Z. Bian, R. Holt, M. Du, H. Jin, R. Bedi, and M. Fan, "Caries experience and oral health behavior in Chinese children with cleft lip and/or palate," Pediatric Dentistry, vol. 23, no. 5, pp. 431-434, 2001.

[30] B. Bokhout, F. X. W. M. Hofman, J. van Limbeek, G. J. C. Kramer, and B. Prahl-Andersen, "Increased caries prevalence in 2.5-year-old children with cleft lip and/or palate," European Journal of Oral Sciences, vol. 104, no. 5-6, pp. 518-522, 1996.

[31] T. Paul and R. S. Brandt, "Oral and dental health status of children with cleft lip and/or palate," Cleft Palate-Craniofacial Journal, vol. 35, no. 4, pp. 329-332, 1998.

[32] C. Turner, A. Zagirova, L. Frolova, F. J. Courts, and W. N. Williams, "Oral health status of Russian children with unilateral cleft lip and palate," Cleft Palate-Craniofacial Journal, vol. 35, no. 6, pp. 489-494, 1998.
[33] B. Bokhout, C. van Loveren, F. X. W. M. Hofman, J. F. Buijs, J. van Limbeek, and B. Prahl-Andersen, "Prevalence of Streptococcus mutans and lactobacilli in 18-month-old children with cleft lip and/or palate," Cleft Palate-Craniofacial Journal, vol. 33, no. 5, pp. 424-428, 1996.

[34] C. van Loveren, J. F. Buijs, B. Bokhout, B. Prahl-Andersen, and J. M. Ten Cate, "Incidence of mutans streptococci and lactobacilli in oral cleft children wearing acrylic plates from shortly after birth," Oral Microbiology and Immunology, vol. 13, no. 5, pp. 286-291, 1998.

[35] F. W. L. Wong and N. M. King, "The oral health of children with clefts-a review," Cleft Palate-Craniofacial Journal, vol. 35, no. 3, pp. 248-254, 1998.

[36] World Health Organization, Oral Health Surveys: Basic Methods, World Health Organization, Geneva, Switzerland, 1987.

[37] I. Saxén, "Epidemiology of cleft lip and palate: an attempt to rule out chance correlations," British Journal of Preventive and Social Medicine, vol. 29, no. 2, pp. 103-110, 1975.

[38] A. R. Vieira and I. M. Orioli, "Birth order and oral clefts: a meta analysis," Teratology, vol. 66, no. 5, pp. 209-216, 2002.

[39] A. R. Vieira, I. M. Orioli, and J. C. Murray, "Maternal age and oral clefts: a reappraisal," Oral Surgery, Oral Medicine, Oral Pathology, Oral Radiology, and Endodontics, vol. 94, no. 5, pp. 530-535, 2002.

[40] A. P. Vanderas, "Incidence of cleft lip, cleft palate, and cleft lip and palate among races: a review," Cleft Palate Journal, vol. 24, no. 3, pp. 216-225, 1987.

[41] P. A. Mossey and J. Little, "Epidemiology of oral clefts: an international perspective," in Cleft Lip \& Palate. From Origin to Treatment, D. F. Wyszynski, Ed., pp. 127-158, Oxford University Press, New York, NY, USA, 2002.

[42] A. R. Vieira, J. C. Karras, I. M. Orioli, E. E. Castilla, and J. C. Murray, "Genetic origins in a South American clefting population," Clinical Genetics, vol. 62, no. 6, pp. 458-463, 2002.

[43] A. R. Vieira, "Unraveling human cleft lip and palate research," Journal of Dental Research, vol. 87, no. 2, pp. 119-125, 2008.

[44] J. R. Lukacs and L. L. Largaespada, "Explaining sex differences in dental caries prevalence: saliva, hormones, and "life history" etiologies," American Journal of Human Biology, vol. 18, no. 4, pp. 540-555, 2006.

[45] J. R. Lukacs, "Sex differences in dental caries experience: clinical evidence, complex etiology," Clinical Oral Investigations. In press.

[46] A. R. Vieira, M. L. Marazita, and T. Goldstein-McHenry, "Genome-wide scan finds suggestive caries loci," Journal of Dental Research, vol. 87, no. 5, pp. 435-439, 2008.

[47] K. Deeley, A. Letra, E. K. Rose et al., "Possible association of amelogenin to high caries experience in a guatemalan-mayan population," Caries Research, vol. 42, no. 1, pp. 8-13, 2008.

[48] A. Patir, F. Seymen, M. Yildirim et al., "Enamel formation genes are associated with high caries experience in Turkish children," Caries Research, vol. 42, no. 5, pp. 394-400, 2008. 


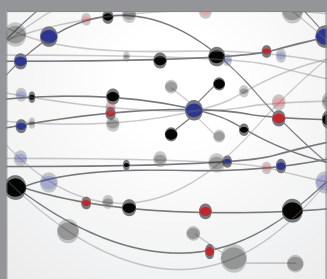

The Scientific World Journal
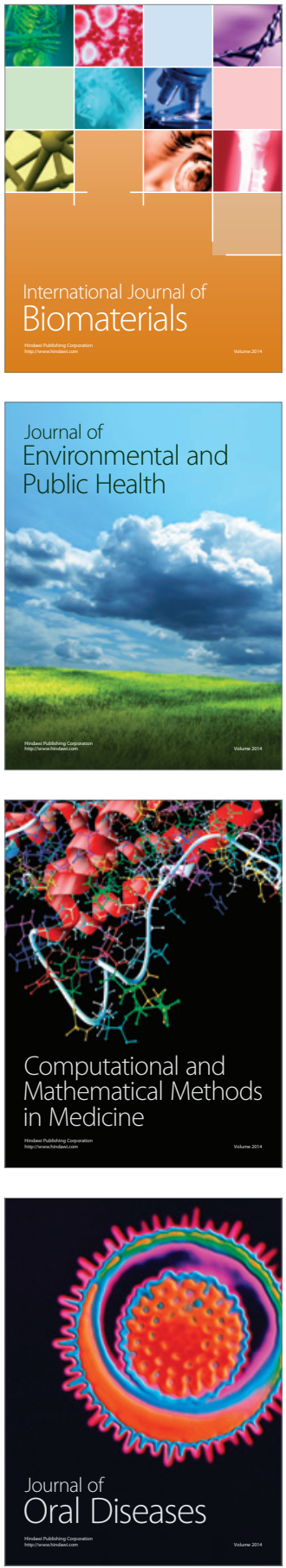
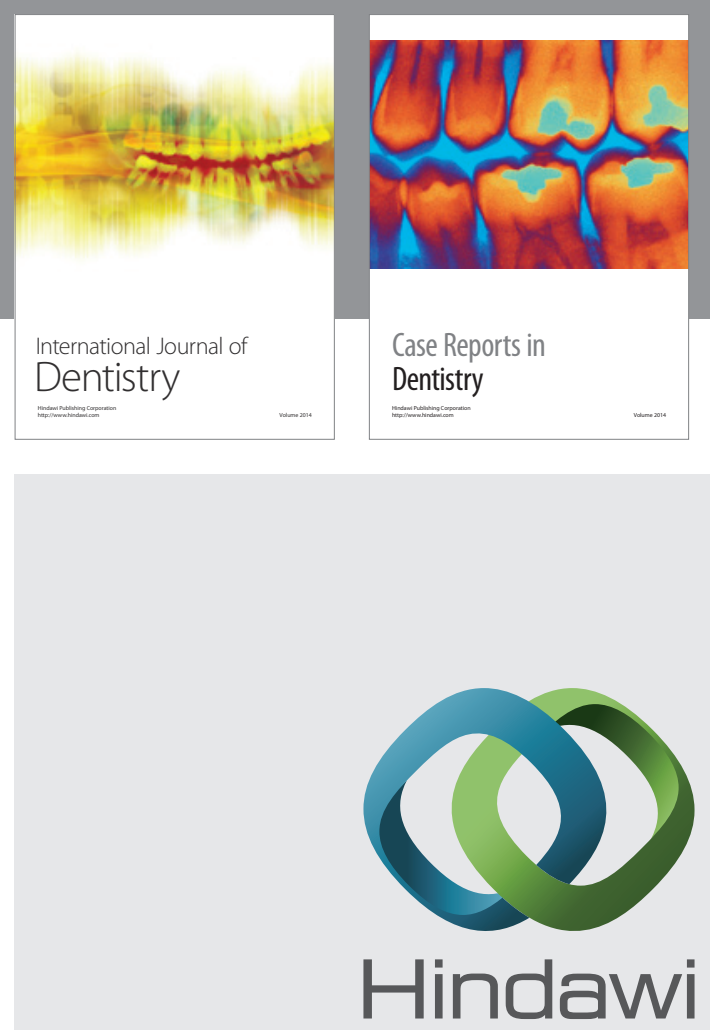

Submit your manuscripts at

http://www.hindawi.com
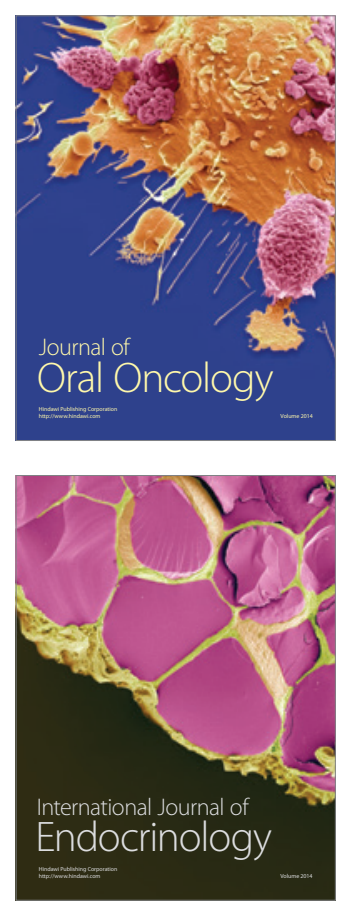
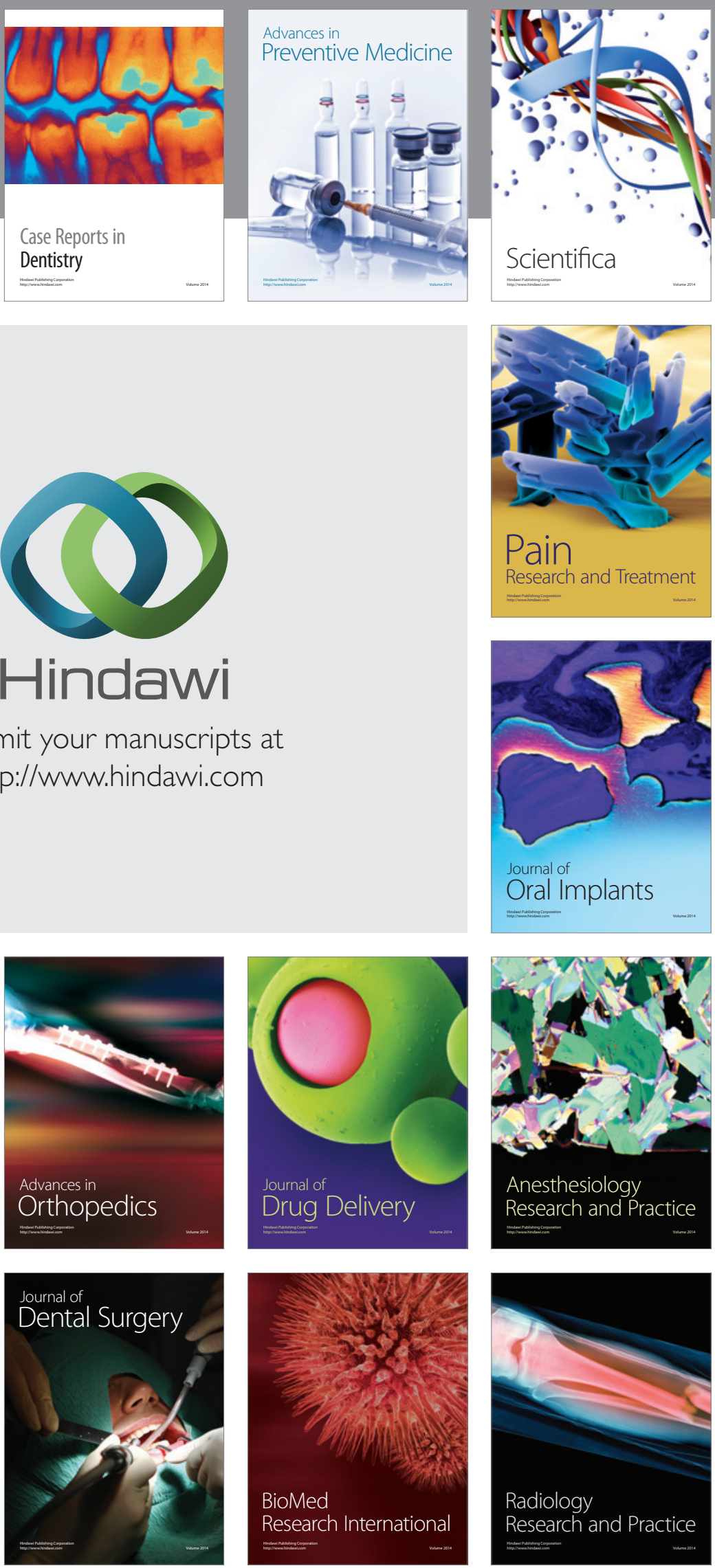